\title{
Fecal Antibiotic Resistome of Pigs from a Small-Scale Piggery in Ibadan, South-West Nigeria
}

\author{
Oluseyi A. Olayinka ${ }^{1}$, Temitope O.C. Faleye ${ }^{2}$, Oladipo O. Omotosho ${ }^{3}$, Oladapo A. Odukaye ${ }^{3}$, Bolaji \\ Oluremi $^{4}$, Ibipeju H. Ibitoye ${ }^{1}$, Oludayo O. Ope-Ewe ${ }^{1}$, Uwem E. George ${ }^{5}$, Oluwadamilola A. Arowolo ${ }^{6}$, \\ Ijeoma M. Ifeorah ${ }^{7}$, Ewean C. Omoruyi ${ }^{8}$, Emmanuel Donbraye ${ }^{9}$, Olufunke P. Adeniji ${ }^{10}$, Olubusuyi M. \\ Adewumi ${ }^{1,11 *}$ and Johnson A. Adeniji ${ }^{1,11,12}$
}

${ }^{1}$ Department of Virology, Faculty of Basic Medical Sciences, College of Medicine, University of Ibadan, Ibadan, Nigeria; ${ }^{2}$ Center for Human Virology and Genomics, Department of Microbiology, Nigerian Institute of Medical Research, Lagos State, Nigeria; ${ }^{3}$ Department of Veterinary Medicine, Faculty of Veterinary Medicine, University of Ibadan, Ibadan, Nigeria; ${ }^{4}$ Department of Pharmaceutical Microbiology, Faculty of Pharmacy, University of Ibadan, Ibadan, Nigeria; ${ }^{5}$ Department of Biological Sciences, Redeemer's University, Ede, Nigeria; ${ }^{6}$ Viral Vaccines Production Division, National Veterinary Research Institute, Vom, Plateau State, Nigeria; ${ }^{7}$ Department of Medical Laboratory Sciences, Faculty of Health Sciences and Technology, University of Nigeria, Nsukka, Nigeria; ${ }^{8}$ Institute of Child Health, College of Medicine, University of Ibadan, Ibadan, Nigeria; ${ }^{9}$ Department of Medical Microbiology and Parasitology, Obafemi Awolowo University, Ile-Ife, Nigeria; ${ }^{10}$ Department of Transport and Tourism, Redeemers University, Ede, Nigeria; ${ }^{11}$ Infectious Diseases Institute, College of Medicine, University of Ibadan; ${ }^{12}$ WHO National Polio Laboratory, University of Ibadan, Ibadan, Nigeria.

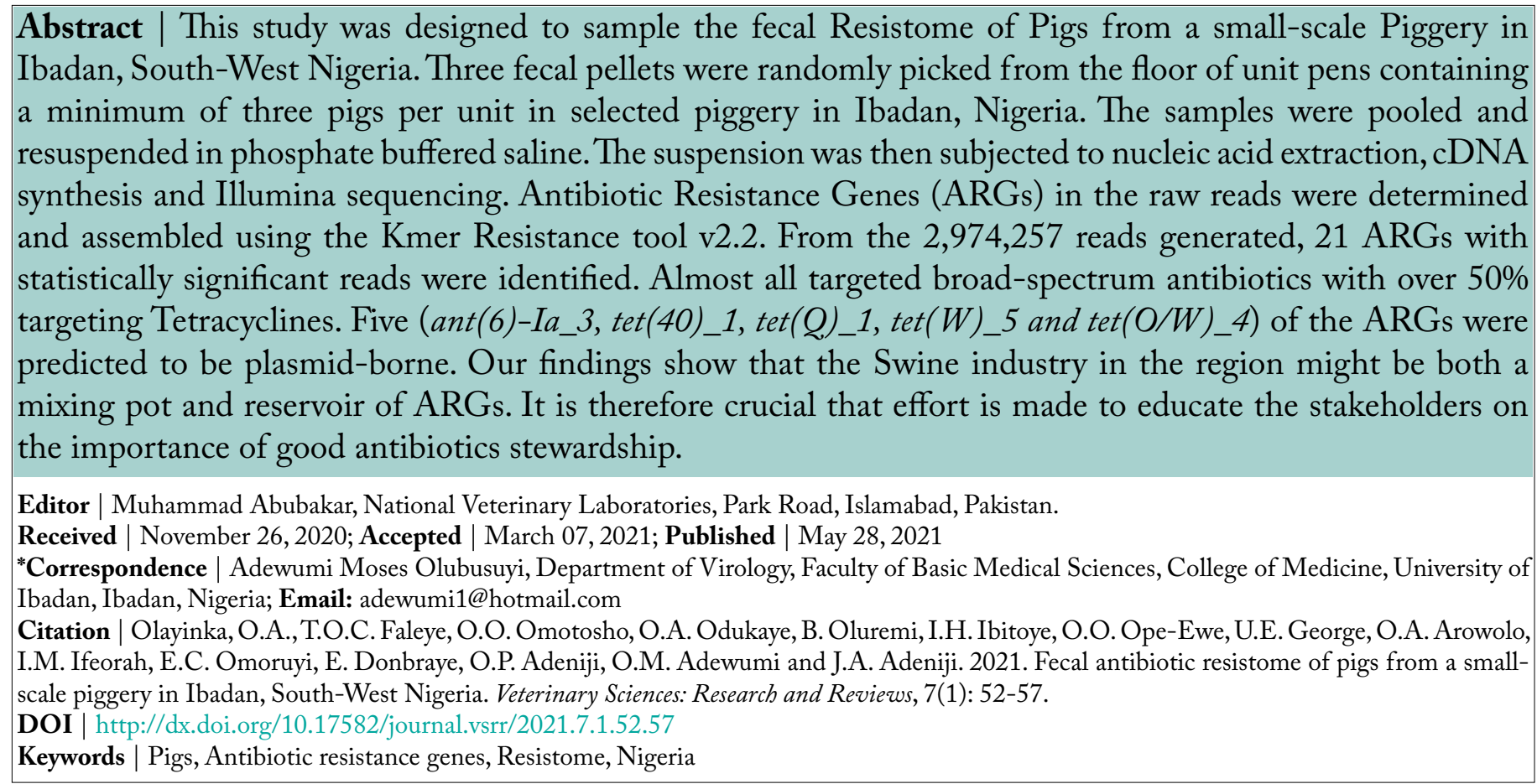

\section{Introduction}

$\mathrm{T}$ he core message of the One-Health movement is the fact that human health is on an intricate balance pivoted by the entire health of physical environment and surrounding livestock and game animals (Ryu et al., 2017; World Bank, 2010). This fragile relationship has been well documented in 
istory especially of outbreaks in human populations deductions from the proliferation of small scale and caused by zoonotic pathogen spillover events peasant pig farming show possibility of increased (Woolhouse and Gaunt, 2007; Daszak et al., 2000; pig population in Nigeria. Moreover, in recent years, Jones et al., 2008) As humans, our most intimate and there is a conspicuous renewed interest in swine economic interactions with animals are livestock, production, partly, due to their prolificacy, impressive hence, we have a significant amount of documented growth rate, relative hardiness and ability to thrive zoonotic outbreaks originating from livestock to on readily available agro-industrial waste products humans (Woolhouse and Gaunt, 2007; Daszak et al., especially in the face of dwindling disposable income 2000; Jones et al., 2008).

Swine production is a major sector in the livestock industry in Nigeria with over 7.1 million pigs as of 2011 (Igbokwe and Maduka, 2018). Critically, there is paucity of data on population statistics of domestic animals in Nigeria, however, inferential and the increasing population in Nigeria. In south west Nigeria, many small-scale piggeries exist and contribute significantly to meat production in the region. These facilities have 1 to 50 pigs and on occasion consult with Veterinarians and other Animal Health Experts (AHEs) for health services. However due to the small-scale nature of these businesses,

Table 1: Antibiotic resistance genes recovered from pig feces during this study.

\begin{tabular}{|c|c|c|c|c|c|c|c|c|c|c|c|c|}
\hline $\begin{array}{l}\text { S. } \\
\text { No }\end{array}$ & $\begin{array}{l}\text { Antibiotic resistance } \\
\text { gene }\end{array}$ & Score & $\begin{array}{l}\text { Ex- } \\
\text { pected }\end{array}$ & $\begin{array}{l}\text { Template } \\
\text { length }\end{array}$ & q_value & p_value & $\begin{array}{l}\text { Tem- } \\
\text { plate id }\end{array}$ & $\begin{array}{l}\text { Template } \\
\text { coverage }\end{array}$ & $\begin{array}{l}\text { Query } \\
\text { id }\end{array}$ & $\begin{array}{l}\text { Query } \\
\text { coverage }\end{array}$ & Depth & $\begin{array}{l}\text { Depth } \\
\text { corr }\end{array}$ \\
\hline 1 & ant(6)-Ia_3_KF864551 & 8670 & 99 & 867 & 8376.88 & $1.00 \mathrm{E}-26$ & 100 & 100 & 100 & 100 & 10.01 & 0.9267 \\
\hline 2 & ant(6)-Ia_1_AF330699 & 1311 & 106 & 909 & 1023.7 & $1.00 \mathrm{E}-26$ & 71.4 & 72.28 & 98.78 & 138.36 & 1.55 & 0.3328 \\
\hline 3 & ant(6)-Ib_1_FN594949 & 1212 & 100 & 858 & 941.34 & $1.00 \mathrm{E}-26$ & 85.78 & 85.78 & 100 & 116.58 & 1.41 & 0.308 \\
\hline 4 & aph(3')-III_1_M26832 & 1058 & 93 & 795 & 808.72 & $1.00 \mathrm{E}-26$ & 70.06 & 71.82 & 97.55 & 139.23 & 1.45 & 0.3152 \\
\hline 5 & aph(3")-Ib_5_AF321551 & 1056 & 94 & 804 & 804.27 & $1.00 \mathrm{E}-26$ & 69.4 & 69.78 & 99.47 & 143.32 & 1.35 & 0.2971 \\
\hline 6 & blaACI-1_1_AJ007350 & 1403 & 100 & 855 & 1129.45 & $1.00 \mathrm{E}-26$ & 92.28 & 94.27 & 97.89 & 106.08 & 1.74 & 0.3651 \\
\hline 7 & erm(B)_1_JN899585 & 2306 & 86 & 738 & 2060.01 & $1.00 \mathrm{E}-26$ & 92.01 & 92.01 & 100 & 108.69 & 3.13 & 0.5583 \\
\hline 8 & mef(A)_3_AF227520 & 6135 & 140 & 1218 & 5726.1 & $1.00 \mathrm{E}-26$ & 80.79 & 84.56 & 95.53 & 118.25 & 5.98 & 0.7901 \\
\hline 9 & lnu(C)_1_AY928180 & 1915 & 57 & 495 & 1748.28 & $1.00 \mathrm{E}-26$ & 88.28 & 89.49 & 98.65 & 111.74 & 4.07 & 0.6545 \\
\hline 10 & sul2_1_AF542061 & 870 & 95 & 816 & 620.93 & $1.00 \mathrm{E}-26$ & 61.52 & 61.64 & 99.8 & 162.23 & 1.08 & 0.2457 \\
\hline 11 & $\begin{array}{l}\operatorname{tet}(44) \_1 \_N Z \\
\text { ABDU01000081 }\end{array}$ & 3419 & 223 & 1923 & 2802.72 & $1.00 \mathrm{E}-26$ & 66.46 & 67.76 & 98.08 & 147.58 & 1.89 & 0.3895 \\
\hline 12 & tet(44)_2_FN594949 & 5962 & 221 & 1923 & 5327.9 & $1.00 \mathrm{E}-26$ & 84.87 & 85.86 & 98.85 & 116.47 & 3.24 & 0.5709 \\
\hline 13 & tet(40)_1_FJ158002 & 14470 & 137 & 1221 & 14063.63 & $1.00 \mathrm{E}-26$ & 99.84 & 100 & 99.84 & 100 & 12.09 & 0.9574 \\
\hline 14 & tet $(\mathrm{Q})$ _1_L33696 & 137368 & 131 & 1926 & 136975.1 & $1.00 \mathrm{E}-26$ & 99.95 & 100 & 99.95 & 100 & 72.88 & 1 \\
\hline 15 & tet(Q)_2_X58717 & 6447 & 222 & 1926 & 5810.56 & $1.00 \mathrm{E}-26$ & 68.59 & 70.61 & 97.13 & 141.62 & 3.59 & 0.6083 \\
\hline 16 & $\operatorname{tet}(\mathrm{Q}) \_4 \_Z 21523$ & 10658 & 219 & 1926 & 10018.42 & $1.00 \mathrm{E}-26$ & 90.08 & 91.85 & 98.08 & 108.88 & 5.83 & 0.7818 \\
\hline 17 & tet(W)_2_AY049983 & 5619 & 221 & 1920 & 4987.07 & $1.00 \mathrm{E}-26$ & 93.18 & 95.83 & 97.23 & 104.35 & 3.09 & 0.5537 \\
\hline 18 & tet(W)_5_AJ427422 & 40577 & 197 & 1920 & 39987.76 & $1.00 \mathrm{E}-26$ & 99.95 & 100 & 99.95 & 100 & 21.66 & 0.9965 \\
\hline 19 & $\operatorname{tet}(\mathrm{O} / \mathrm{W})$ _4_AM889121 & 19724 & 208 & 1889 & 19106.66 & $1.00 \mathrm{E}-26$ & 70.67 & 70.67 & 100 & 141.5 & 10.65 & 0.938 \\
\hline 20 & $\begin{array}{l}\text { tet(O/W/O)-2_1_ } \\
\text { AY196920 }\end{array}$ & 10118 & 218 & 1920 & 9480.22 & $1.00 \mathrm{E}-26$ & 79.79 & 80.16 & 99.55 & 124.76 & 5.4 & 0.7558 \\
\hline 21 & $\begin{array}{l}\operatorname{tet}(\mathrm{O} / 32 / \mathrm{O})_{-}{ }_{-} \\
\text {FP929050 }\end{array}$ & 8174 & 220 & 1920 & 7536.75 & $1.00 \mathrm{E}-26$ & 64.27 & 64.64 & 99.44 & 154.71 & 4.38 & 0.6813 \\
\hline
\end{tabular}

Note: Antibiotic Resistance Gene: shows the name of the template sequences; Score: is the global alignment score of the template; Expected: is the expected alignment score if all mapping reads where smeared over all templates in the database; Template length: is the template length in nucleotides; q_value: is the quantile in a standard Pearson Chi-square test, to test whether the current template is a significant hit; __value $_{-}$ is p-value corresponding to the obtained q-value.; Template_id is the percent identity of the found template, over the full template length. Template_coverage is percent of the template that is covered by the query; Query_id is the percent identity between the query and template
sequence, over the length of the matching query sequence; Query_coverage is the length of the matching query sequence divided by the template sequence, over the length of the matching query sequence; Query_coverage is the length of the matching query sequence divided by the template
length; Depth: is the number of times the template has been covered by the query; Depth_Corr: is an Estimate of how good the depth of the urrent template is compared to the found host, a low value would point towards contamination, a value around 0.5 would indicate that the gene is located on the host genome and a value close to 1.0 would indicate that this template is plasmid born

-

open access $_{\text {acto }}$

Veterinary Sciences: Research and Reviews

the managers/farmers tend to quack (Omotosho et 1., 2013, 2016) and self-medicate (based on their experience from previous consultations with AHEs) the animals without consultation with Veterinarians and other AHEs, a practice that has resulted into indiscriminate use, low dosage use in feed and out of prescription use of antimicrobials (Van et al., 2020).

These practices are certain to result in the development of antibiotic resistant bacteria in pigs in the region. Antibiotic resistance (AR) in different bacterial types recovered from Pigs in the region have been documented (Oloso et al., 2018). These studies reviewed with reductionist approach were designed around result in a bacteria by bacterial AR profile and do not give a global view of the constellation of AR genes (ARGs) (called the Resistome) in the bacteriome (Microbiome) of Pigs in the region. Hence, in this study we attempt to sample the Resistome of the fecal Bacteriome of Pigs from a small scale Piggery in Ibadan, south-west Nigeria.

Materials and Methods

Sample collection

Fecal samples of pigs were analysed in this study. The fecal samples were collected in June 2018 from a Pig farm in Ibadan, Oyo State, south-west Nigeria. The sample is a pool made from fecal pellets on the floor of a Pen containing three Pigs. Three independent randomly selected fecal pellets were selected. Each pellet was broken and about 3grams from the core was inserted in a $15 \mathrm{~mL}$ centrifuge tube. All three pellets were collected into the same sample tube.

Processing for illumina sequencing

The fecal pool was resuspended in phosphate buffered saline (PBS). Afterward, nucleic acid was extracted from the suspension using the DNA/RNA extraction kit (Jena Biosceince, Jena, Germany). Subsequently, cDNA was synthesized using the SCRIPT cDNA synthesis kit (Jena Biosceince, Jena, Germany). This was then shipped to a commercial facility (MR DNA, Texas, USA) where library preparation and sequencing was done. The library was prepared using the TruSeq ${ }^{\mathrm{TM}}$ RNA LT Sample Preparation Kit (Illumina) as recommended by the manufacturer. Subsequently, sequencing was done paired end for 300 cycles using the HiSeq system (Illumina).

Bioinformatic analysis

The quality of the raw reads was assessed using the

June 2021 | Volume 7 | Issue 1 | Page 54
FSTOC tool v1.0.4. Subsequently, the ARGs in the row reads were determined and assembled using the Kmer Resistance tool v2.2 (https://cge.cbs.dtu.dk/ services/KmerResistance/) with default parameters (Clausen et al., 2018) The detected and assembled ARGs were then downloaded, visually screened and those for which single contigs exceeded 200bp were further analyzed and submitted to GenBank under the accession numbers MK286928, MK293762MK293776.

\section{Results and Discussion}

From the 2,974,257 reads generated, 21 ARGs with statistically significant reads were identified (Table 1). Almost all the ARGs detected targeted broadspectrum antibiotics and fell into three modes of action (Table 2). Precisely, 90.5\% (19/21) of the ARGs detected target drugs that inhibit translation. The remaining $9.5 \%(2 / 21)$ inhibit cell wall synthesis $(b l a A C l)$ and nucleic acid synthesis by disruption of single-carbon metabolism (sul2). Estimates of how good the depth of the current template is compared to that found in host (Table 1; Depth corr $>0.8$ ) suggest that some (ant (6)-Ia_3, tet $(40) \_1$, tet $(Q) \_1$, tet $(W) \_5$ and tet $\left.(\mathrm{O} / W) \_4\right)$ of the ARGs detected are likely to be plasmid borne. The complete coding sequence (CDS) of four of the five (5) genes that seem to be plasmid borne were recovered.

Diversity of ARGs detected and what it implies for antibiotic use

In this study we investigated the Resistome of Pigs farmed on a small scale piggery in Ibadan, south-west, Nigeria in an effort to appraise what it will reveal about antibiotic use in Piggery in the region. Particularly, we sequenced cDNA. Hence, might be assessing genes that were expressed in the fecal microbiom of the Pigs. In all, we detected 21 ARGs (Table 1) which target drugs that inhibit translation, cell wall synthesis and nucleic acid synthesis (Table 2). While antibiotics that inhibit translation and nucleic acid synthesis are broad-spectrum, the current generation of antibiotics that inhibit cell wall synthesis could also be broad-spectrum. The results of this study therefore show that almost all the ARGs detected, target broadspectrum antibiotics. This suggests a possible ongoing treatment of the animals in the farm and dependence on broads spectrum antibiotics in Swine management in the region. 


\begin{tabular}{|c|c|c|c|c|c|}
\hline $\begin{array}{l}\text { S. } \\
\text { No }\end{array}$ & Mode of action & $\begin{array}{l}\text { Antibiotic re- } \\
\text { sistance gene }\end{array}$ & $\begin{array}{l}\text { Class of target } \\
\text { drug }\end{array}$ & $\begin{array}{l}\text { Cheapest brand available } \\
\text { locally and commonly used } \\
\text { in piggery }\end{array}$ & Resistance mechanism \\
\hline 1 & Inhibition of translation & ant(6)-Ia_3 & aminoglycoside & Gentamycin and Amikacin & Aminoglycoside adenyltransferases \\
\hline 2 & Inhibition of translation & ant(6)-Ia_1 & aminoglycoside & Gentamycin and Amikacin & Aminoglycoside adenyltransferases \\
\hline 3 & Inhibition of translation & ant $(6)-\mathrm{Ib} \_1$ & aminoglycoside & Gentamycin and Amikacin & Aminoglycoside adenyltransferases \\
\hline 4 & Inhibition of translation & aph(3')-III_1 & aminoglycoside & Gentamycin and Amikacin & $\begin{array}{l}\text { Aminoglycoside } \\
\text { phosphotransferases }\end{array}$ \\
\hline 5 & Inhibition of translation & aph(3")-Ib_5 & aminoglycoside & Gentamycin and Amikacin & $\begin{array}{l}\text { Aminoglycoside } \\
\text { phosphotransferases }\end{array}$ \\
\hline 6 & Inhibition of translation & erm(B)_1 & macrolide & Erythromycin and Tylosin & Erm $23 \mathrm{~S}$ rRNA methyltransferases \\
\hline 7 & Inhibition of translation & mef(A)_3 & macrolide & Erythromycin and Tylosin & Macrolide resistance efflux pumps \\
\hline 8 & Inhibition of translation & $\operatorname{lnu}(\mathrm{C}) \_1$ & lincosamide & Lincomycin and Clindamycin & $\begin{array}{l}\text { Lincosamide nucleotidyltransferase } \\
\text { (Lin) }\end{array}$ \\
\hline 9 & Inhibition of translation & tet(44)_1_NZ & Tetracycline & Oxytetracycline $20 \%$ & $\begin{array}{l}\text { Tetracycline resistance ribosomal } \\
\text { protection proteins }\end{array}$ \\
\hline 10 & Inhibition of translation & tet(44)_2 & Tetracycline & Oxytetracycline $20 \%$ & $\begin{array}{l}\text { Tetracycline resistance ribosomal } \\
\text { protection proteins }\end{array}$ \\
\hline 11 & Inhibition of translation & tet(40)_1 & Tetracycline & Oxytetracycline $20 \%$ & $\begin{array}{l}\text { Tetracycline resistance ribosomal } \\
\text { protection proteins }\end{array}$ \\
\hline 12 & Inhibition of translation & tet $(\mathrm{Q}) \_1$ & Tetracycline & Oxytetracycline $20 \%$ & $\begin{array}{l}\text { Tetracycline resistance ribosomal } \\
\text { protection proteins }\end{array}$ \\
\hline 13 & Inhibition of translation & $\operatorname{tet}(\mathrm{Q}) \_2$ & Tetracycline & Oxytetracycline $20 \%$ & $\begin{array}{l}\text { Tetracycline resistance ribosomal } \\
\text { protection proteins }\end{array}$ \\
\hline 14 & Inhibition of translation & $\operatorname{tet}(\mathrm{Q}) \_4$ & Tetracycline & Oxytetracycline $20 \%$ & $\begin{array}{l}\text { Tetracycline resistance ribosomal } \\
\text { protection proteins }\end{array}$ \\
\hline 15 & Inhibition of translation & $\operatorname{tet}(\mathrm{W}) \_2$ & Tetracycline & Oxytetracycline $20 \%$ & $\begin{array}{l}\text { Tetracycline resistance ribosomal } \\
\text { protection proteins }\end{array}$ \\
\hline 16 & Inhibition of translation & $\operatorname{tet}(\mathrm{W}) \_5$ & Tetracycline & Oxytetracycline $20 \%$ & $\begin{array}{l}\text { Tetracycline resistance ribosomal } \\
\text { protection proteins }\end{array}$ \\
\hline 17 & Inhibition of translation & $\operatorname{tet}(\mathrm{O} / \mathrm{W})_{-} 4$ & Tetracycline & Oxytetracycline $20 \%$ & $\begin{array}{l}\text { Tetracycline resistance ribosomal } \\
\text { protection proteins }\end{array}$ \\
\hline 18 & Inhibition of translation & $\begin{array}{l}\text { tet } \\
(\mathrm{O} / \mathrm{W} / \mathrm{O})-2 \_1\end{array}$ & Tetracycline & Oxytetracycline $20 \%$ & $\begin{array}{l}\text { Tetracycline resistance ribosomal } \\
\text { protection proteins }\end{array}$ \\
\hline 19 & Inhibition of translation & tet $(\mathrm{O} / 32 / \mathrm{O})_{-} 7$ & Tetracycline & Oxytetracycline $20 \%$ & $\begin{array}{l}\text { Tetracycline resistance ribosomal } \\
\text { protection proteins }\end{array}$ \\
\hline 20 & $\begin{array}{l}\text { Inhibition of cell wall } \\
\text { synthesis or disruption of } \\
\text { membrane }\end{array}$ & blaACI-1_1 & beta-Lactamase & & Class A $\beta$-lactamases \\
\hline 21 & $\begin{array}{l}\text { Inhibition of nucleic acid } \\
\text { synthesis by disruption of }\end{array}$ & sul2_1_ & sulfonamide & $\begin{array}{l}\text { Sulfafurazole and } \\
\text { Sulfasomidine }\end{array}$ & $\begin{array}{l}\text { Sulfonamide-resistant } \\
\text { dihydropteroate synthases }\end{array}$ \\
\hline
\end{tabular}

Considering that farm managers tend to self-medicate for consumption. Consequently, AHEs treat the Pigs the pigs based on previous consultations with AHEs, it based on symptoms and recommend broad spectrum is likely that AHEs in the region use broad-spectrum antibiotics to ensure that the infection is controlled, antibiotics significantly. This could be due to economic irrespective of the etiological agent. The consequence reasons. Specifically, most of the small-scale Pig farm of this practice is the accumulation of resistance to managers are not (even if recommended) willing to broad spectrum antibiotics in the intestinal/feca pay for laboratory diagnosis of any clinical condition bacteriome of Pigs in the region; as documented in in their few farm animals. Rather, sick animals are this study. sold to slaughter houses or slaughtered on the farm open AcCESS $_{\text {A }}$

Veterinary Sciences: Research and Reviews

It should be noted that over 50\% (Tables 1 and 2) made to educate the stake-holders on the importance of the ARGs detected in this study are targeted of good antibiotics stewardship. in Tetracyclines. This is not surprising because, in addition to using Tetracyclines for treatment (or prevention) of infections, Tetracyclines like chlortetracycline and oxytetracycline are used at suboptimal levels for their animal growth-promoting properties (Gustafson and Kiser, 1985; Aerestrup, 2015) This allows the emergence of AR bacteria by giving selective advantage to strains with ARGs specific for the administered antibiotic. Hence, the combination of using Tetracyclines for both growth promotion and treatment, encourages emergence of Tetracycline resistance genes and subsequently selects for it in the Pig microbiome.

Plasmid encoded ARGS and horizontal gene transfer

The results of this study showed that some (ant(6) Ia_3, tet $(40) \_1$, tet $(Q) \_1$, tet $(W) \_5$ and $\left.\operatorname{tet}(\mathrm{O} / W) \_4\right)$ of the ARGs detected are likely to be Plasmid borne. Our findings in this respect conform with what is documented in literature (Mendez et al. 1980; Jones et al., 1992; Recchia and Hall, 1995; Chopra and Robert, 2001). Being plasmid borne, these ARGs targeted at broad-spectrum antibiotic are transferred horizontally and consequently, spread among and between bacterial species. Ryu et al (2017) Considering zoonotic spread of pathogen from Pigs to Humans, it is not surprising that these plasmid-borne ARGs (targeting broad spectrum antibiotics) are present in the intestinal microbiome of humans (Chopra and Robert, 2001). We however posit that they are likely to be present at higher rates in livestock handlers in the region. This has serious health implications for the people working in the Swine and allied industries. It is therefore importan that the prevalence of ARGs targeted at broad spectrum antibiotics in this population be determined as it might directly impact the treatment of bacterial infections in these population.

In summary, we sampled the Resistome of Pigs farmed on a small-scale piggery in Ibadan, southwest, Nigeria and found 21 ARGs that target broad spectrum antibiotics that inhibit translation, cell wall synthesis and nucleic acid synthesis. Our data also suggest that some of these ARGs might be plasmid borne and consequently involved in horizontal gene transfer. Finally, our findings show that the Swine industry in the region might be both a mixing pot and reservoir of ARGs. It is therefore crucial that effort is Acknowledgements

We thank the farmers and handlers in Ibadan, southwest Nigeria for allowing us to take fresh faeces from the floor of their Pen.

\section{Novelty Statement}

This study particularly is the first of its kind to focus primarily on Antibiotic Resistance Genes (ARGs)/ Antibiotic Resistome from faecal materials of domestic pigs (Sus scrofa domesticus) in farm settlements of pig businesses in Ibadan. The study reports $21 \mathrm{ARG}$ with global scores and especially for the first time rewith global scores and especially for the first time re-
porting the ARG; Lnu(C)_1 from the Drug Class Lincosamide, a broad-spectrum antibiotic used in Ibadan city, Southwest Nigeria.

Author's Contribution

TOCF, OMA and JAA conceptualized the research All authors were involved in sample collection and laboratory preparation of samples. TOCF analyzed the data and interpreted the results. OMA and JAA supervised the work. All authors were responsible for writing and reviewing the final manuscript.

Funding

This research did not receive any specific grant from funding agencies in the public, commercial, or notfor-profit sectors.

Conflict of interest

The authors have declared no conflict of interest.

Ethics approval

Not required. Sampling was not invasive and was precisely done without contact with the Pigs.

Availability of data and material

Sequence data generated from the study have been submitted to GenBank under the accession numbers MK286928, MK293762-MK293776

References

Aarestrup, F.M., 2015. The livestock reservoir for antimicrobial resistance: A personal 
view on changing patterns of risks, effects of interventions and the way forward.Philos. Trans. R. Soc. London, B, Biol. Sci., 3(70): 20140085. https://doi.org/10.1098/rstb.2014.0085

Chopra, I. and Roberts, M., 2001. Tetracycline antibiotics: Mode of action, applications, molecular biology, and epidemiology of bacterial resistance. Microbiol. Mol. Biol. Rev., 65(2): 232-260. https://doi.org/10.1128/ MMBR.65.2.232-260.2001

Clausen, P.T.L.C., Aarestrup, F.M. and Lund. O., 2018. Rapid and precise alignment of raw reads against redundant databases with KMA. BMC Bioinf., 19(1): 307. https://doi.org/10.1186/ s12859-018-2336-6

Daszak, P., Cunningham, A.A. and Hyatt, A.D., 2000. Emerging Infectious diseases of wildlife threats to biodiversity and human health. Science,287:443-449.https://doi.org/10.1126/ science.287.5452.443

Gustafson, R.H. and Kiser, J.S., 1985. The tetracyclines. $1^{\text {st }}$ edition. Springer-Verlag KG, Berlin, Germany.

Igbokwe, I.O. and Maduka, C.V., 2018. Disease burden affecting pig production in Nigeria: Review of current issues and challenges. Rev. d'él. Méd. Vét. Pays Trop., 71(1-2): 1-10. https://doi.org/10.19182/remvt.31290

Jones K.E., Patel, N.G., Levy, M.A., Storeygard, A., Balk, D., Gittleman J.L. and Daszak, P., 2008. Global trends in emerging infectious diseases. Nature, 451: 990-993. https://doi.org/10.1038/ nature 06536

Jones, C.S., Osborne, D.J. and Stanley, J., 1992. Enterobacterial tetracycline resistance in relation to plasmid incompatibility. Mol. Cell. Probes, 6: 313-317. https://doi.org/10.1016/08908508(92)90007-K

Mendez, B., Tachibana, C. and Levy, S.B., 1980. Heterogeneity of tetracycline resistance determinants. Plasmid, 3: 99-108. https://doi. org/10.1016/0147-619X(80)90101-8

Oloso, N.O., Fagbo, S., Garbati, M., Olonitola,
S.O., Awosanya, E.J., Aworh, M.K., Adamu, H., Odetokun, I.A. and Fasina, F.O., 2018. Antimicrobial resistance in food animals and the environment in Nigeria: A review. Int. J. Environ. Res.Publ.Health, 15(6): 1284. https:// doi.org/10.3390/ijerph15061284

Omotosho, O.O., Abiola, J.O. and Olufemi, B.E., 2013. Prevalence, predisposing factors and antibiogram of swine skin abscess in selected farms in Ibadan, Nigeria. Trop. Vet., 31(4): 190198.

Omotosho,O.O.,Olaogun,S.C. and Odukaye,A.O., 2016. Occurrence of skin abscess and sensitivity pattern of associated bacterial organisms in pigs on ifelodun farm settlement, Ogun State, Nigeria. Alex. J. Vet. Sci., 2016, 51(1): 10-16. https://doi.org/10.5455/ajvs.227437

Recchia, G.D. and Hall, R.M., 1995. Gene cassettes: A new class of mobile element. Microbiology, 141: 3015-3027. https://doi. org/10.1099/13500872-141-12-3015

Ryu, S., Kim, B.I., Lim, J.S., Tan, C.S. and Chun, B.C., 2017. One health perspectives on emerging public health threats. J. Prev. Med. Publ. Health, 50(6): 411-414. https://doi. org/10.3961/jpmph.17.097

Van, T.T.H., Yidana, Z., Smooker, P.M. and Coloe, P.J., 2020. Antibiotic use in food animals worldwide, with a focus on Africa: Pluses and minuses. J. Glob. Antimicrob. Resist., 20: 170177.https://doi.org/10.1016/j.jgar.2019.07.031

Woolhouse, M. and Gaunt, E., 2007. Ecological origins of novel human pathogens. Crit. Rev. Microbiol., 33: 231-242. https://doi. org/10.1080/10408410701647560

Woolhouse, M.E.J. and Gowtage-Sequeria, S., 2005. Host range and emerging and reemerging pathogens. Emerg. Infect. Dis., 11: 1842-1847. https://doi.org/10.3201/eid1112.050997

World Bank, 2010. People, pathogens, and our planet, Vol. 1: Towards a one health approach for controlling zoonotic diseases. Washington, DC: World Bank. 